\title{
Evaluation of Soybean Entries/Varieties against Myrothecium Leaf Spot (Myrothecium roridum) under Field Conditions
}

\section{Meghchand Dewangan, Arvind Kumar Kurre*, R.K. Dantre and Santhosh Kumar Sahu}

Department of Plant Pathology, Indira Gandhi Krishi Vishwavidyalaya,

Raipur - 492001, Chattishgarh, India

*Corresponding author

\begin{tabular}{|l|l}
\hline \multicolumn{1}{c|}{ A B S T R A C T } \\
\cline { 2 - 3 } $\begin{array}{l}\text { Keywords } \\
\begin{array}{l}\text { Myrothecium leaf } \\
\text { spot, soybean, } \\
\text { Myrothecium } \\
\text { roridum. }\end{array}\end{array}$ & $\begin{array}{l}\text { Myrothecium leaf spot of soybean caused by Myrothecium roridum. Fifty } \\
\text { six entries/varieties of soybean were screened under natural field condition } \\
\text { for resistance of myrothecium leaf Spot of soybean. Thirty seven } \\
\text { entries/varieties exhibited highly resistant, sixteen entries/varieties were } \\
\text { found moderately resistant, three entries/varieties were found moderately } \\
\text { susceptible. The maximum PDI was observed in JS 72-44 (40.05\%) } \\
\text { Article Info }\end{array}$ \\
\hline $\begin{array}{l}\text { Accepted: } \\
\text { 26 June 2017 } \\
\text { Available Online: } \\
\text { 10 July 2017 }\end{array}$ & $\begin{array}{l}\text { susceptible grouped and the minimum PDI was recorded in JS 72-280 } \\
\text { highly resistant grouped. None of the entries/varieties were categorized in } \\
\text { absolutely resistant, susceptible and highly susceptible categories. }\end{array}$ \\
\hline \hline
\end{tabular}

\section{Introduction}

Soybean (Glycine max. (L.) Merril) belonging to family Leguminaceae is designated as miracle bean established its potential as an industrially vital and viable oilseed crop in many areas of India. Leaf spot of soybean is caused by Myrothecium roridum Tode ex.

Fries is an important disease, which occurred in epidemic proportion entailing into colossal losses to soybean crop in Madhya Pradesh (Shrivastava and Khan, 1994, Singh and Shrivastava, 1994).

Myrothecium leaf spot of soybeanis occurring in almost all the major soybean growing areas of India causing about 30 per cent yield loss
(Shrivastava and Khan, 1994). The disease severity of myrothecium leaf spot soybean was in the range of 35 to $45 \%$ and disease incidence of myrothecium leaf spot soybean was in the range of 30 to $55 \%$ (Singh and Shrivastava, 1994). Myrothecium roridumis ordinary soil fungi, and survive in this environment as saprophytes in decaying plant tissues (Ellis, 1971).

Initial symptoms of the disease appear as small round or oval, brown spots with dark brown margin on leaves in the infected plant. Since it is an economically important disease, management of the disease plays crucial role. 
There are numerous reports on resistance varieties to control the disease. Talukdar (2011) reported that out of 56 varieties, 50 varieties showed highly resistant reaction while remaining 6 varieties were found moderately resistant. None of the varieties found in absolutely resistant, moderately susceptible, susceptible and highly susceptible categories.

\section{Materials and Methods}

\section{Experimental site}

The field experiment was conducted at the research farm, IGAU Raipur, in kharif season 2015. Fifty-six soybean entries/varieties were screened which was sown on 4th July 2015. The entries/varieties were sown in three rows of 3.2 mleanthwith the $30 \mathrm{~cm}$ row distance and $5 \mathrm{~cm}$ plant distance.

All the recommended agronomic practices were adopted. The observations on natural occurrence of $M$. roridum on soybean leaf were recorded at regular interval. For calculation of disease severity five plant of each variety were randomly selected and tagged.

Observation on of the disease severity of the foliage was recorded by using 0-9 scale according to Singh et al., (1982) and per cent disease index (PDI) was worked out.

Where,

0 - No lesions

$1-1 \%$ leaf area covered with lesion

$3-1.1-10 \%$ leaf area covered with lesion

$5-10.1-25 \%$ of the leaf area covered no defoliation, little damage

$7-25.1-50 \%$ leaf area covered, some leaf drop, death of a few plant damage conspicuous.

9 -More than $50 \%$ leaf area covered, lesion very common on all plants, defoliation common, death of plant common, damage more than $50 \%$.

PDI was calculated using the formula of Wheeler (1969) as given here

Sum of individual rating Percent Disease Index (PDI) $=$

Number of leaves examined 100

\section{Maximum disease rating}

On the basis of PDI and disease scale of ICAR-IISR 2010-11 the entries/varieties were classified as followed.

\section{Results and Discussion}

The data presented in Table 1 and 2indicates that out of 56 entries/varieties, 37entries/varieties, showed highly resistance reaction, 16 entries/varieties, were found moderately resistant and 3 were found moderately susceptible.

None of the entries/varieties found in absolutely resistant, susceptible and highly susceptible categories.

The maximum PDI was observed in JS 72-44 (40.05\%) followed by NRC 122 (36\%) and JS 71-05 $(35.5 \%)$ under moderately susceptible grouped and the minimum PDI was recorded in JS 72-280 (2.00\%) followed by shivalik (2.20\%) and RSC 10-13 (2.30\%) under highly resistant grouped (Table 2).

From the result, it is clear that maximum entries/varieties exhibited resistant reaction for the disease of Myrothecium leaf spot of soybean. 
PDI and disease scale of ICAR-IISR 2010-11

\begin{tabular}{cl}
\hline \hline Infection $\%$ & Reaction category \\
\hline 0 & Absolutely resistant \\
$0.01-11.11 \%$ & Highly Resistant \\
$11.12-33.33 \%$ & Moderately resistant \\
$33.34-55.55 \%$ & Moderately Susceptible \\
$55.56-77.77 \%$ & Susceptible \\
$77.78 .-100 \%$ & Highly Susceptible \\
\hline
\end{tabular}

Table.1 Percent disease index of various soybean entries

\begin{tabular}{|c|c|c|c|c|c|}
\hline S. N. & $\begin{array}{c}\text { Name of } \\
\text { entries }\end{array}$ & $\begin{array}{c}\text { Percent disease } \\
\text { index }\end{array}$ & S. N. & $\begin{array}{c}\text { Name of } \\
\text { entries }\end{array}$ & $\begin{array}{c}\text { Percent disease } \\
\text { index }\end{array}$ \\
\hline 1 & JS 75-46 & 4.50 & 29 & TS 72 & 3.80 \\
\hline 2 & JS 72-280 & 2.00 & 30 & DS 3103 & 3.00 \\
\hline 3 & PK 262 & 2.50 & 31 & NRC 118 & 10.50 \\
\hline 4 & PK 472 & 3.50 & 32 & PS 1572 & 2.60 \\
\hline 5 & MACS 58 & 6.20 & 33 & MACS 1480 & 3.40 \\
\hline 6 & JS 93-05 & 5.20 & 34 & AMS100-1 & 4.50 \\
\hline 7 & Punjab1 & 4.10 & 35 & Himso 1686 & 8.90 \\
\hline 8 & Bragg & 5.10 & 36 & KDS 775 & 9.00 \\
\hline 9 & Monetta & 5.00 & 37 & VLS 90 & 10.10 \\
\hline 10 & KHSB 2 & 5.60 & 38 & JS 72-44 & 40.50 \\
\hline 11 & VLS 58 & 3.20 & 39 & JS 71-05 & 35.50 \\
\hline 12 & NRC 7 & 2.50 & 40 & JS 335 & 13.00 \\
\hline 13 & Shivalik & 2.20 & 41 & KDS754 & 12.00 \\
\hline 14 & PS 1569 & 4.10 & 42 & RVS 2010-2 & 13.00 \\
\hline 15 & RVS 2010-1 & 4.40 & 43 & RSC 10-29 & 14.00 \\
\hline 16 & DSb 30-2 & 4.50 & 44 & MAUS 740 & 22.00 \\
\hline 17 & RSC 10-13 & 2.30 & 45 & NRS 122 & 36.00 \\
\hline 18 & MACS 1491 & 3.40 & 46 & KBS 24-2014 & 24.50 \\
\hline 19 & JS 20-94 & 4.10 & 47 & JS 20-116 & 17.00 \\
\hline 20 & NRC 117 & 6.50 & 48 & AMS1001 & 18.50 \\
\hline 21 & AMS 115 & 7.50 & 49 & NRC 123 & 19.50 \\
\hline 22 & KDS 975 & 8.10 & 50 & SL 1074 & 24.50 \\
\hline 23 & VLS 91 & 7.60 & 51 & NRC 120 & 30.00 \\
\hline 24 & NRC 119 & 6.60 & 52 & TS 69 & 23.50 \\
\hline 25 & DSb 29 & 4.90 & 53 & BAUS 72 & 22.50 \\
\hline 26 & PS 1570 & 3.90 & 54 & MACS 1488 & 25.00 \\
\hline 27 & DS 3104 & 4.80 & 55 & VLB 202 & 21.50 \\
\hline 28 & MAUS 710 & 4.90 & 56 & NRC 121 & 25.00 \\
\hline
\end{tabular}


Table.2 Evaluation of soybean entries against myrothecium leaf spot under field conditions

\begin{tabular}{|c|c|c|c|}
\hline Infection \% & $\begin{array}{c}\text { Disease } \\
\text { reaction }\end{array}$ & $\begin{array}{c}\text { Number of } \\
\text { entries }\end{array}$ & Name of entries \\
\hline 0 & $\begin{array}{l}\text { Absolutely } \\
\text { resistant }\end{array}$ & 0 & \\
\hline $0.01-11.11$ & $\begin{array}{l}\text { Highly } \\
\text { Resistant }\end{array}$ & 37 & $\begin{array}{l}\text { JS 75-46, JS 72-280, PK 262, PK 472, } \\
\text { MACS 58, JS 93-05, Punjab1, Bragg, } \\
\text { Monetta, KHSB 2, NRC 7, VLS 58, } \\
\text { Shivalik, PS 1569, RVS 2010-1,DSb } \\
\text { 30-2, RSC 10-13, MACS 1491, JS 20- } \\
\text { 94, NRC 117, AMS 115, KDS 975, } \\
\text { VLS 91, MAUS 710, TS 72, DS 3103, } \\
\text { NRC 118, PS 1572, MACS 1480, AMS } \\
\text { 100-1, Himso 1686, KDS 775, VLS 90, } \\
\text { NRC } 119 \text {, DSb 29, PS 1570, DS 3104, }\end{array}$ \\
\hline $11.12-33.33$ & $\begin{array}{l}\text { Moderately } \\
\text { resistant }\end{array}$ & 16 & $\begin{array}{l}\text { SL } 1074 \text {, NRC } 120 \text {, TS } 69 \text {, BAUS } 72 \text {, } \\
\text { MACS } 1488 \text {, VLB } 202 \text {, NRC } 121 \text {, JS } \\
335 \text { KDS } 754 \text {, RVS } 2010-2 \text {, RSC } 10- \\
29 \text {, MAUS } 740 \text {, KBS } 24-2014 \text {, JS } 20- \\
116 \text {, AMS } 1001 \text {, NRC } 123\end{array}$ \\
\hline $33.34-55.55$ & $\begin{array}{l}\text { Moderately } \\
\text { Susceptible }\end{array}$ & 3 & JS 72-44, JS 71-05, NRS 122 \\
\hline 55.56.-77.77 & Susceptible & 0 & \\
\hline 77.78-100 & $\begin{array}{l}\text { Highly } \\
\text { Susceptible }\end{array}$ & 0 & \\
\hline
\end{tabular}

Present finding are in accordance with Singh and Srivastava (1994) who reported only two of the 26 cultivars as resistant for three consecutive years (1984-86), three were moderately resistant and the rest were moderately to highly susceptible against Myrothecium leaf spot disease. Srivastava $e t$ al., (1994) recorded JS 81-303, JS 81-1619 and JS 81-335 as highly resistant varieties against Myrothecium leaf spot of soybean. Talukdar (2011) reported maximum varieties exhibited highly resistant reaction like PK472 for the disease of Myrothecium leaf spot of soyabean.

In conclusion, the present study in evaluation of soybean entries/varieties against myrothecium leaf spot under field conditions reported that out of 56 entries /varieties, 37 entries /varieties, showed highly resistance reaction, 16 entries /varieties, were found moderately resistant and 3 were found moderately susceptible and effective in reducing the disease severity under field conditions.

\section{References}

Ellis, M.B. (1971). Dematiaceous Hyphomycetes. Kew. CMI.

Shrivastava, S.K. and Khan, S.U (1994).Impact of host age at infection time on the severity of Myrothecium leaf spot disease of soybean. Indian Phytopatho, 47(2): 190-191.

Singh, S.M. and Shrivastava, S.K. (1994). Screening of soybean varieties against leaf spot disease caused by 
Myrotheciumroridum. Indian Journal of Mycology and Plant Pathology, 24(3): 222.

Talukdar, D. 2011.Studies on myrothecium leaf spot (Myrotheciumroridum) tode ex fries. Of soyabean. MSc. Ag. Thesis, Indira Gandhi Krishi Vishwavidyala, Raipur, p. 61.

\section{How to cite this article:}

Meghchand Dewangan, Arvind Kumar Kurre, R.K. Dantre and Santhosh Kumar Sahu. 2017. Evaluation of Soybean Entries/Varieties against Myrothecium Leaf Spot (Myrothecium roridum) under Field Conditions. Int.J.Curr.Microbiol.App.Sci. 6(7): 2447-2451. doi: https://doi.org/10.20546/ijcmas.2017.607.347 